\title{
Electrodeposition of Cadmium Sulfide and Lead (II) Sulfide onto Polycrystalline Gold Electrode
}

\section{Polikristalin Altın Elektrot Üzerine Kadmiyum Sülfür ve Kurşun (II) Sülfürün Elektrodepozisyonu}

\author{
Özge Sürücü ${ }^{1,2}$ \\ ${ }^{1}$ Department of Chemistry, Faculty of Science, Hacettepe University, Ankara, Turkey. \\ ${ }^{2}$ Department of Chemistry, Faculty of Science, Ege University, Izmir, Turkey.
}

\section{ABSTRACT}

\begin{abstract}
new, simple and cost-effective electrochemical route was demontrated in this work. CdS and PbS thin films were grown Aon polycrystalline gold electrode using co-deposition and ECALE techniques based on accumulation layer by layer. The deposition potentials of cadmium, lead and sulfur were determined separately by cyclic voltammetry. Thin films were created from an electrolyte containing $0.01 \mathrm{molL}^{-1} \mathrm{CdSO}_{4}, 0.01 \mathrm{molL}^{-1} \mathrm{Na}_{2} \mathrm{~S}$ and $\left.0.01 \mathrm{molL}^{-1} \mathrm{~Pb}_{\left(\mathrm{CH}_{3} \mathrm{COO}\right.}\right)_{2}$ in $0.01 \mathrm{molL}^{-1} \mathrm{EDTA}(\mathrm{pH}=$ 3.00). The influence of bath temperature at the deposition potential was studied to determine the crystallinity of deposits. From the chronoamperometry results including the transients which were obtained within the under potential region, the overall shape of the experimental depositions was proposed and the growth process was considered.
\end{abstract}

\section{Key Words}

Underpotential deposition, co-deposition, ECALE.

u çalışmada yeni, basit ve uygun maliyetli bir elektrokimyasal rutin gösterildi. CdS ve PbS ince filmler polikristalin altın elektrot üzerinde tabaka tabaka biriktirme temeliyle ko-depozisyon ve ECALE teknikleri kullanılarak büyütüldü. Kadmiyum, kurşun ve kükürdün biriktirme potansiyelleri ayrı ayrı dönüşümlü voltametri ile belirlendi. İnce filmler $0.01 \mathrm{molL}^{-1}$ EDTA'da ( $\mathrm{pH}=3.00) 0.01 \mathrm{molL}^{-1} \mathrm{CdSO}_{4}, 0.01 \mathrm{molL}^{-1} \mathrm{Na}_{2} \mathrm{~S}$ ve $\left.0.01 \mathrm{molL}^{-1} \mathrm{~Pb}_{\left(\mathrm{CH}_{3} \mathrm{COO}\right.}\right)_{2}$ içeren elektrolitten oluşturuldular. Biriktirme potansiyelindeki sıcaklık etkisi birikintilerin kristalliğinin belirlenmesi için çalışıldı. Potansiyel altı alanı içerisinde elde edilen geçişleri kapsayan kronoamperometri sonuçlarından, deneysel birikimlerin genel şekilleri önerildi ve büyüme süreci değerlendirildi.

\section{Anahtar Kelimeler}

Potansiyel altı biriktirme, ko-depozisyon, ECALE. 


\section{INTRODUCTION}

C admium ( $\mathrm{Cd}$ ) and lead $(\mathrm{Pb})$ are electroactive heavy metals, so they can be detected electrochemically. The monitoring of $\mathrm{Cd}$ and $\mathrm{Pb}$ using sensitive, inexpensive and portable electrochemical methods is an attractive way to determine hazardous heavy metals [1]. At the same time, II-VI semiconductors like cadmium sulfide (CdS) have a wide application in the non-linear optical materials, solar cells, light-emitting diodes, electronic and optoelectronic devices [2] and IV-VI semiconductors like lead (II) sulfide (PbS) are also focused on fieldeffect thin film transistors, single-electron transistors and flat-panel displays [3]. In such an important field, deposition of these materials is coming into prominence and electrochemistry is a good alternative to conventional deposition methods with a number of advantages such as film thickness control, operation at ambient temperature and pressure $[4,5]$.

Under potential deposition (UPD) is an electrodeposition technique based on the reduction of a metal cation to a solid metal at a more positive potential than the equilibrium (Nernst) potential for the reduction of this metal [6]. UPD is generally occurs as a result of a strong interaction between the electrodepositing metal (M) and the substrate (S) which is used to construct the electrode. The M-S interaction must be energetically active to the $M-M$ interaction in the crystal lattice of the pure M. Such a process is developed by the observation of UPD which can occur up to a monolayer or two monolayers of $\mathrm{M}$. The reference point for the UPD is characterized by the electrodeposition of $\mathrm{M}$ on a $\mathrm{S}$ of the same $\mathrm{M}$ taking place at an equilibrium potential [7].

As one of the UPD method, electrolytic co-deposition is an electroplating method which consists of the mixing of non-metallic particles into metallic coatings obtained from electrolytes containing the particles in a suspended state [8]. The second phase particles like ethylenediaminetetraacetic acid (EDTA) which dispersed within the metal base such as $\mathrm{Cd}$ and $\mathrm{Pb}$ form a metal matrix composite (CdEDTA2- and PbEDTA2-) and these composites may show different properties from those of the pure metallic deposits $\left(\mathrm{Cd}^{2+}\right.$ and $\left.\mathrm{Pb}^{2+}\right)$. This method is widely applied to create CdS [9] and PbS [10] thin films in single-crystalline forms, but a little effort is made to overcome the problem of polycrystalline deposits.
Electrochemical atomic layer epitaxy (ECALE) is an atomic layer deposition technique based on UPD where an atomic layer of the element is deposited on the surface by an electrochemical surface limited reaction using an electrochemical cell, at an electrode potential lower than it is needed to deposit the element on itself [11]. In ECALE of CdS and PbS: an atomic layer of cadmium or lead is deposited, followed by an atomic layer of sulfur deposition on the cadmium or lead, and then one of cadmium or lead is again deposited on the sulfur as proposed by Stickney [12].

In this work, the electrodepositions of cadmium and lead together with sulfur onto polycrystalline gold electrode were compared using various techniques including co-deposition and ECALE for the first time. Bulk electrolysis and cyclic voltammetry techniques were applied to determine key parameters such as the deposition potential, deposition time and the effect of temperature. At the same time, chronoamperometry method was used to define the dimensionality of the resulting deposits. The present work mainly aims using of polycrystalline surfaces instead of single crystal surfaces which possess a time-consuming preparation procedure to detect not only hazardous heavy metals, but also to create binary systems and thin films by proposed practical new approach.

\section{MATERIALS and METHODS}

\section{Chemicals}

Before starting the analysis, gold electrode was mechanically polished with 0.05 and $1.00 \mu \mathrm{m}$ superfine alumina $\left(\mathrm{Al}_{2} \mathrm{O}_{3}\right)$ powders and then cleaned electrochemically with successive cycling in $1.00 \mathrm{molL}^{-1}$ sulphuric acid $\left(\mathrm{H}_{2} \mathrm{SO}_{4}\right)$ solution from Sigma-Aldrich between - 0.20 $\mathrm{V}$ and $+1.50 \mathrm{~V}$ versus $\mathrm{Ag} / \mathrm{AgCl}$ until a steady state current was obtained. The prepared $0.01 \mathrm{moll}^{-1}$ EDTA at $\mathrm{pH}$ $=3.00$ was used as a supporting electrolyte. Cadmium sulfate $\left(\mathrm{CdSO}_{4}\right)$, sodium sulfide $\left(\mathrm{Na}_{2} \mathrm{~S}\right)$ and lead (II) acetate $\left(\mathrm{Pb}\left(\mathrm{CH}_{3} \mathrm{COO}\right)_{2}\right)$ solutions from Sigma-Aldrich were prepared in the concentration amount of $0.01 \mathrm{moll}^{-1}$. All the other reagents were in analytical grade. At the beginning of analysis, pure $\mathrm{N}_{2}$ gas was passed from all of the prepared solutions for sufficient period of time to extract oxygen. 

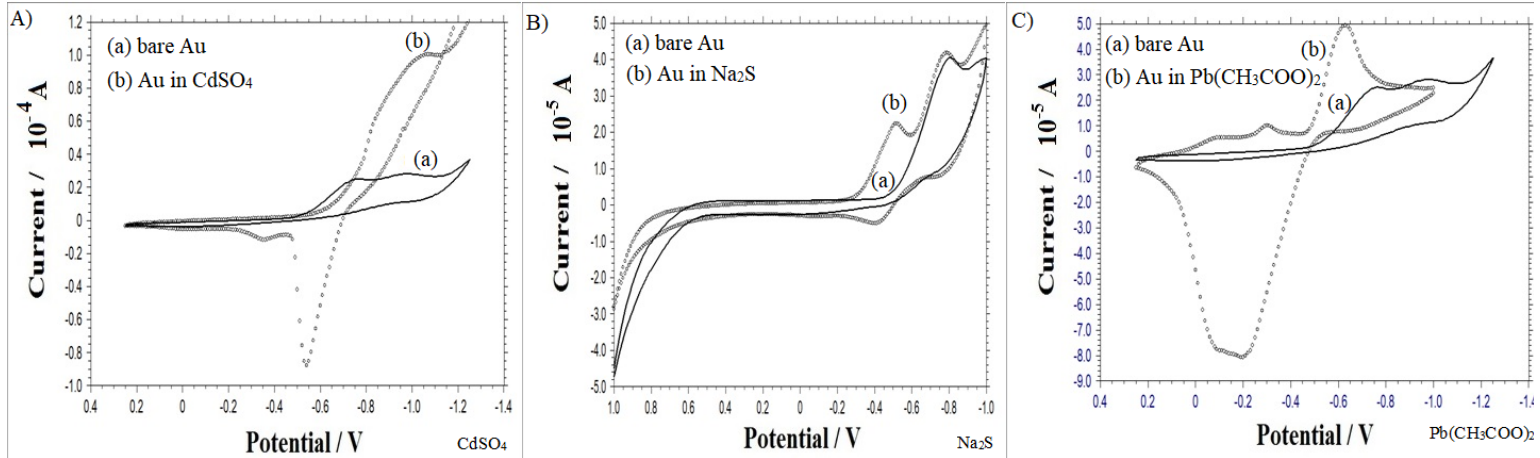

Figure 1. Cyclic voltammograms of bare $\mathrm{Au}$ in $0.01 \mathrm{molL}^{-1} \mathrm{EDTA}(\mathrm{a})$, and $\mathrm{Au}$ in $0.01 \mathrm{molL}^{-1} \mathrm{EDTA}$ containing A) $0.01 \mathrm{molL}^{-1} \mathrm{CdSO}_{4}$ between $+0.25 \mathrm{~V}$ and $-1.25 \mathrm{~V}$ versus $\mathrm{Ag} / \mathrm{AgCl}, \mathrm{B}) 0.01 \mathrm{molL}^{-1} \mathrm{Na}_{2} \mathrm{~S}$ between $+1.00 \mathrm{~V}$ and $-1.00 \mathrm{~V}$ versus $\left.\mathrm{Ag} / \mathrm{AgCl}, \mathrm{C}\right) 0.01 \mathrm{molL}^{-1} \mathrm{~Pb}\left(\mathrm{CH}_{3} \mathrm{COO}\right)_{2}$ between $+0.25 \mathrm{~V}$ and $-1.25 \mathrm{~V}$ versus $\mathrm{Ag} / \mathrm{AgCl}(\mathrm{b})$, at a scan rate of $100 \mathrm{mV} \mathrm{s}^{-1}$.

\section{Instruments}

Bulk electrolysis and cyclic voltammetry techniques were performed on $\mathrm{CH}$ Instruments $\mathrm{CHI660C}$ model potentiostat in the three electrode setup for electrochemical cells comprising platinum (Pt) wire as the counter electrode, silver/silver chloride $(\mathrm{Ag} / \mathrm{AgCl})$ as the reference electrode and gold ( $\mathrm{Au}$ ) electrode with $0.03 \mathrm{~cm}^{2}$ area as working electrode. Bulk electrolysis was done at $-0.35 \mathrm{~V}$ versus $\mathrm{Ag} / \mathrm{AgCl}$ for $\mathrm{Cd},-0.52 \mathrm{~V}$ versus $\mathrm{Ag} / \mathrm{AgCl}$ for $\mathrm{S}$ and $-0.10 \mathrm{~V}$ for $\mathrm{Pb}$ versus $\mathrm{Ag} / \mathrm{AgCl}$ for 10 minutes. Cyclic voltammetry was applied between $+0.25 \mathrm{~V}$ and $-1.60 \mathrm{~V}$ versus $\mathrm{Ag} / \mathrm{AgCl}$ for 10 cycles, and the direction of potential scan was from negative to positive. Chronoamperometry technique was performed between $+0.10 \mathrm{~V}$ and $-0.35 \mathrm{~V}$ versus $\mathrm{Ag} / \mathrm{AgCl}$ for $\mathrm{Cd},+0.60 \mathrm{~V}$ and $-0.43 \mathrm{~V}$ versus $\mathrm{Ag} / \mathrm{AgCl}$ for $\mathrm{Pb}$.

\section{Mechanism of co-deposition and ECALE of cadmium sulfide and lead (II) sulfide}

In the mechanism of co-deposition, the second phase particles (EDTA) suspended in the electrolyte adsorb the positively charged metal ions $\left(\mathrm{Cd}^{2+}\right.$ and $\left.\mathrm{Pb}^{2+}\right)$. The metal ions enclose the EDTA particles and the resulting complexes (CdEDTA ${ }^{2-}$ and PbEDTA ${ }^{2-}$ ) arrive at the cathode taking action by the electrostatic attraction and the electrolyte convection. The particles stayed at the cathode surface discharge and the three related interfacial energies including particle-electrolyte, particle-cathode and cathode-electrolyte help to retain the particles on the surface by the bonding force. The metal ions are deposited on the cathode surface around the particles mixing into the metallic deposits. In the case of sulfur, anodic deposition is obtained on the anode surface.
Each pair of elements has its own UPD chemistry and it must be investigated to discover its proper ECALE cycle. Such a cycle is the sequence of steps used to deposit one stoichiometric layer of the targeted element which can be an atomic layer for a pure element, or a bi-layer of a 1:1 compound. CdS or PbS cycle is composed of several steps: initially a reductive UPD of cadmium or lead from a cadmium or lead cation solution, then oxidative UPD of sulfur from a sulfide anion solution, and finally a second reductive UPD of cadmium or lead from a cadmium or lead cation solution. Separate solutions are used for each material and different potentials for each cycle step. The use of separate solutions and potentials has a lot of advantages such as extensive control over deposit growth, composition and morphology. At the same time, it is avoided from the oxidation of metal surface before sulfurization by means of each species own potential. The cycle is repeated to form a thin film because the deposit thickness is a linear function of the number of cycles. Such a linear relation is a good indication of a layer by layer mechanism, and an atomic layer deposition process.

\section{RESULTS and DISCUSSION}

\section{UPD of cadmium, sulfur and lead}

The formation of the first monolayer is inferred from the declared current peaks at the potential $E>E_{\text {rev }}$ while the bulk deposition occurs at $E<E_{\text {rev }}$ where $E_{\text {rev }}$ specifies the Nernstian equilibrium potential [13]. As it is known, $E_{\text {rev }}$ is $-0.46 \mathrm{~V}$ versus $\mathrm{Ag} / \mathrm{AgCl}$ for $\mathrm{Cd} / \mathrm{Cd}^{2+}$ and $-0.19 \mathrm{~V}$ versus $\mathrm{Ag} / \mathrm{AgCl}$ for $\mathrm{Pb} / \mathrm{Pb}^{2+}$. In (Figure $1 \mathrm{~A}$ ), cyclic voltammogram 

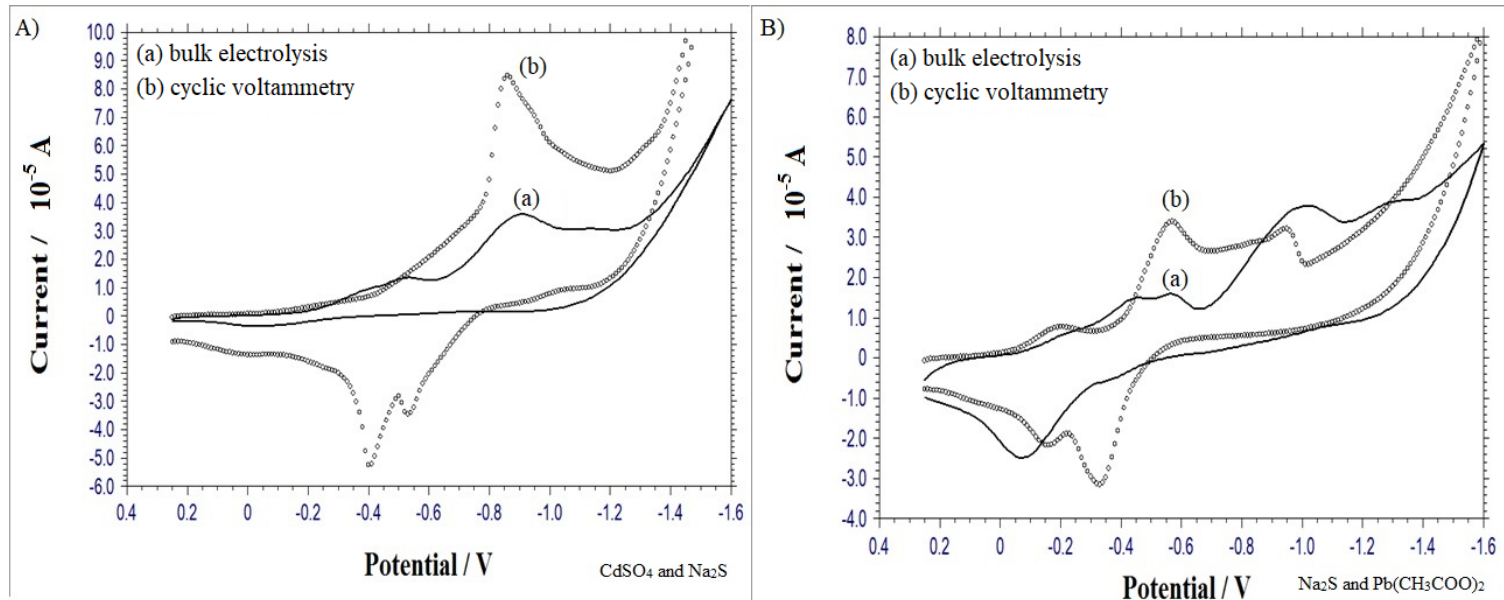

Figure 2. Cyclic voltammograms of bulk electrolyzed Au for 10 minutes (a), and coated Au for 10 cycles (b) in A) 0.01 molL $^{-1}$ EDTA conta- $^{-1}$ ining $0.01 \mathrm{molL}^{-1} \mathrm{CdSO}_{4}$ and $0.01 \mathrm{molL}^{-1} \mathrm{Na}_{2} \mathrm{~S}$ and B) $0.01 \mathrm{molL}^{-1}$ EDTA containing $0.01 \mathrm{molL}^{-1} \mathrm{Na}_{2} \mathrm{~S}$ and $0.01 \mathrm{molL}^{-1} \mathrm{~Pb}\left(\mathrm{CH}_{3} \mathrm{COO}\right)_{2}$ between +0.25 and $-1.60 \mathrm{~V}$ versus $\mathrm{Ag} / \mathrm{AgCl}$ at a scan rate of $100 \mathrm{mV} \mathrm{s}^{-1}$.

of Au electrode in $0.01 \mathrm{molL}^{-1}$ EDTA containing $0.01 \mathrm{molL}^{-1}$ $\mathrm{CdSO}_{4}$ was compared with bare Au electrode behavior in $0.01 \mathrm{molL}^{-1}$ EDTA, and bulk potential of $\mathrm{Cd}$ was obtained at $-0.55 \mathrm{~V}$ (less than $-0.46 \mathrm{~V}$ ) versus $\mathrm{Ag} / \mathrm{AgCl}$, UPD potential at $-0.35 \mathrm{~V}$ (more than $-0.46 \mathrm{~V}$ ) versus $\mathrm{Ag} / \mathrm{AgCl}$ [14]. In (Figure $1 \mathrm{C}$ ), cyclic voltammogram of Au electrode in 0.01 molL-1 EDTA containing $0.01 \mathrm{molL}^{-1} \mathrm{~Pb}\left(\mathrm{CH}_{3} \mathrm{COO}\right)_{2}$ was compared with bare Au electrode behavior in $0.01 \mathrm{molL}^{-1}$ EDTA. A broad peak was observed between $-0.20 \mathrm{~V}$ and $0.00 \mathrm{~V}$ versus $\mathrm{Ag} / \mathrm{AgCl}$, but two side by side peaks were actually gained. Bulk potential of $\mathrm{Pb}$ was obtained at $-0.23 \mathrm{~V}$ (less than $-0.19 \mathrm{~V}$ ) versus $\mathrm{Ag} / \mathrm{AgCl}$, UPD potential at $-0.10 \mathrm{~V}$ (more than $-0.19 \mathrm{~V}$ ) versus $\mathrm{Ag} / \mathrm{AgCl}$ [15]. In the case of $\mathrm{S}$, cyclic voltammogram of Au electrode in $0.01 \mathrm{molL}^{-1}$ EDTA containing $0.01 \mathrm{molL}^{-1} \mathrm{Na}_{2} \mathrm{~S}$ was compared with bare $\mathrm{Au}$ electrode behavior in 0.01 molL $^{-1}$ EDTA, but anodic potentials were estimated instead of cathodic potentials (Figure $1 \mathrm{~B})$. The bulk potential of $\mathrm{S}$ was obtained at $-1.00 \mathrm{~V}$ versus $\mathrm{Ag} / \mathrm{AgCl}$, UPD potential at $-0.52 \mathrm{~V}$ versus $\mathrm{Ag} / \mathrm{AgCl}$ and all results were essentially identical to that reported in literature [16].

\section{Bulk electrolysis versus cyclic voltammetry}

After the determination of UPD potentials of $\mathrm{Cd}, \mathrm{S}$ and $\mathrm{Pb}$, the deposition of species were made using both bulk electrolysis and cyclic voltammetry techniques. Bulk electrolysis was applied at $-0.35 \mathrm{~V}$ versus $\mathrm{Ag} / \mathrm{AgCl}$ for $\mathrm{Cd},-0.52 \mathrm{~V}$ versus $\mathrm{Ag} / \mathrm{AgCl}$ for $\mathrm{S},-0.10 \mathrm{~V}$ versus $\mathrm{Ag} /$ $\mathrm{AgCl}$ for $\mathrm{Pb}$ for 10 minutes while cyclic voltammetry was applied between +0.25 and $-1.60 \mathrm{~V}$ versus $\mathrm{Ag} / \mathrm{AgCl}$ for 10 cycles. The methodological difference in the voltammetric behavior of Au electrode in $0.01 \mathrm{molL}^{-1}$ EDTA con- taining $0.01 \mathrm{molL}^{-1} \mathrm{CdSO}_{4}$ and $0.01 \mathrm{molL}^{-1} \mathrm{Na}_{2} \mathrm{~S}$ (Figure 2 A) and in $0.01 \mathrm{molL}^{-1}$ EDTA containing $0.01 \mathrm{molL}^{-1} \mathrm{Na}_{2} \mathrm{~S}$ and $0.01 \mathrm{molL}^{-1} \mathrm{~Pb}\left(\mathrm{CH}_{3} \mathrm{COO}\right)_{2}$ (Figure $2 \mathrm{~B}$ ) was determined, and the UPD peaks of $\mathrm{Cd}, \mathrm{S}$ and $\mathrm{Pb}$ were lost in the event of bulk electrolysis. Therefore, the layer formation was performed by increasing number of cycle. The phase purities of $\mathrm{CdS}$ and $\mathrm{PbS}$ deposited on polycrystalline Au electrode were uniform, so flower-like structures were proposed at long-deposition times [17].

\section{Co-deposition versus ECALE}

Cyclic voltammetric responses of Au electrode using codeposition method based on deposition from the same solution of the precursors of the target compound at a constant UPD potential, and using ECALE method based on deposition of each element from their separate solutions at the UPD potential of each element were represented in (Figure 3). In co-deposition method (a), S UPD $(-0.52 \mathrm{~V}$ versus $\mathrm{Ag} / \mathrm{AgCl})$ disappeared, but in ECALE behavior of $\mathrm{S}$ over $\mathrm{Cd}$ modified Au electrode (c), both $\mathrm{Cd}(-0.35 \mathrm{~V}$ versus $\mathrm{Ag} / \mathrm{AgCl})$ and S UPD peaks were observed by a sharper result than $\mathrm{Cd}$ over $\mathrm{S}$ modified $\mathrm{Au}$ electrode (b) presenting the layer formation of $S$ over $\mathrm{Cd}$ modified $\mathrm{Au}$ electrode (Figure 3A). In the mechanism of $\mathrm{CdS}$ electrodeposition, $\mathrm{Cd}$ reduction $\left(\mathrm{Cd}^{2+}+2 \mathrm{e}\right.$ $=\mathrm{Cd}(\mathrm{UPD}))$ and $\mathrm{S}$ oxidation $\left(\mathrm{S}^{2-}=\mathrm{S}(\mathrm{UPD})+2 \mathrm{e}^{-}\right)$occured as 1:1. An atomic layer of $\mathrm{S}$ was deposited on one of $\mathrm{Cd}$, and one of $\mathrm{Cd}$ was deposited on one of S.

In the case of $\mathrm{Pb}$ and $\mathrm{S}$ co-deposition method (a), both $\mathrm{Pb}$ and S UPD peaks were monitored at the actual UPD potentials of $\mathrm{Pb}(-0.10 \mathrm{~V}$ versus $\mathrm{Ag} / \mathrm{AgCl})$ and $\mathrm{S}(-0.52 \mathrm{~V}$ 

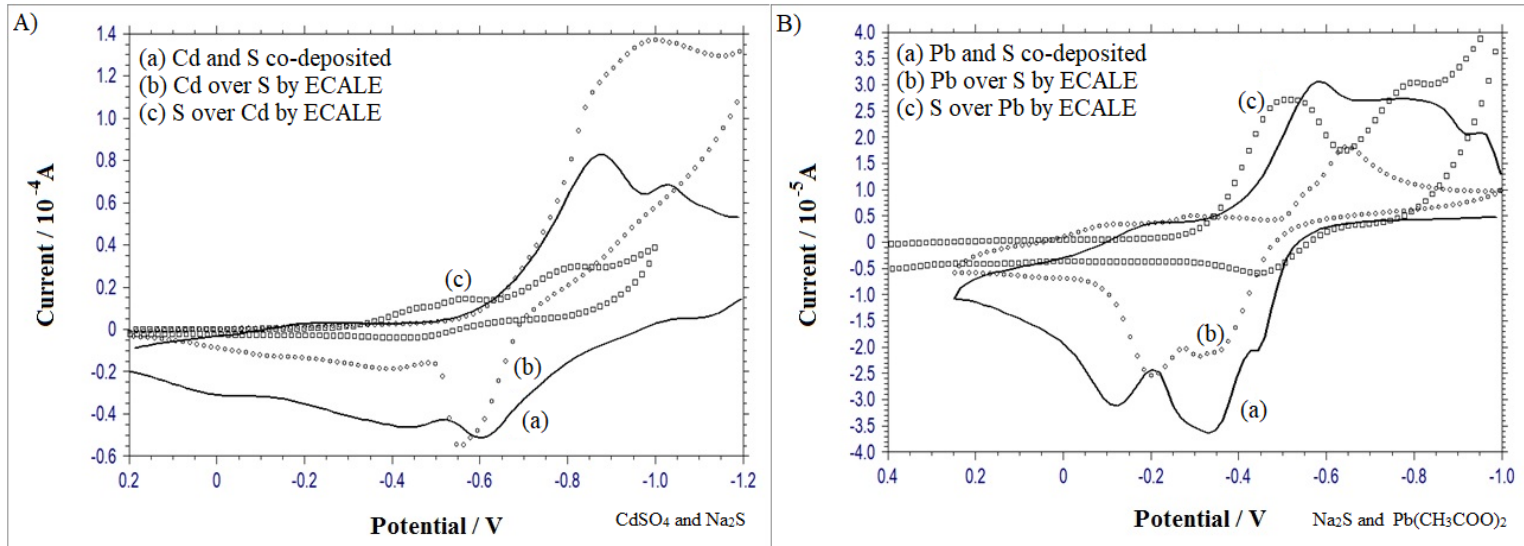

Figure 3. Cyclic voltammograms of coated Au for 10 cycles in A) $0.01 \mathrm{molL}^{-1}$ EDTA containing $0.01 \mathrm{molL}^{-1} \mathrm{CdSO}_{4}$ and $0.01 \mathrm{molL}^{-1} \mathrm{Na}_{2} \mathrm{~S}$ using

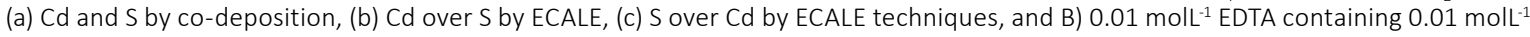
$\mathrm{Na}_{2} \mathrm{~S}$ and $0.01 \mathrm{molL}^{-1} \mathrm{~Pb}\left(\mathrm{CH}_{3} \mathrm{COO}\right.$ ) using (a) $\mathrm{Pb}$ and $\mathrm{S}$ by co-deposition, (b) Pb over $\mathrm{S}$ by ECALE, (c) S over Pb by ECALE techniques between +0.25 and $-1.60 \mathrm{~V}$ versus $\mathrm{Ag} / \mathrm{AgCl}$ at a scan rate of $100 \mathrm{mV} \mathrm{s}^{-1}$.

versus $\mathrm{Ag} / \mathrm{AgCl})$, but in ECALE result of Pb over S modified Au electrode (b), UPD potential of Pb shifted more negative potential $(-0.20 \mathrm{~V}$ versus $\mathrm{Ag} / \mathrm{AgCl})$ weakening the interactions of $\mathrm{Pb}$ with the substrate [18], and in $\mathrm{S}$ over $\mathrm{Pb}$ modified Au electrode response by ECALE (c), $\mathrm{Pb}$ UPD was lost (Figure 3B). Therefore, PbS layer was created using co-deposition technique from the same solutions of $\mathrm{Pb}$ and $\mathrm{S}$. In the mechanism of PbS electrodeposition, $\mathrm{Pb}$ reduction $\left(\mathrm{Pb}^{2+}+2 \mathrm{e}^{-}=\mathrm{Pb}(\mathrm{UPD})\right)$ and $\mathrm{S}$ oxidation $\left(S^{2-}=S(U P D)+2 e^{-}\right)$occured as 1:1. An atomic layer of $\mathrm{S}$ was deposited on one of $\mathrm{Pb}$, and one of $\mathrm{Pb}$ was deposited on one of S.

\section{The effect of bath temperature on UPD}

The influence of bath temperature on UPD was studied and the bath temperature was varied from $25^{\circ} \mathrm{C}$ to $40^{\circ} \mathrm{C}$ to examine the change of composition and microstructure of the deposits. In (Figure 4), the current intensiti- es of bare Au electrode in $0.01 \mathrm{molL}^{-1}$ EDTA containing 0.01 molL $^{-1} \mathrm{CdSO}_{4} \mathrm{~A}$ ), S over $\mathrm{Cd}$ modified Au electrode $\mathrm{B}$ ), and $\mathrm{Cd}$ and $\mathrm{S}$ co-deposited Au electrode $\mathrm{C}$ ) in $0.01 \mathrm{molL}^{-}$ ${ }^{1}$ EDTA containing $0.01 \mathrm{molL}^{-1} \mathrm{CdSO}_{4}$ and $0.01 \mathrm{molL}^{-1} \mathrm{Na}_{2} \mathrm{~S}$ were compared. When the bath temperature was increased from $25^{\circ} \mathrm{C}$ to $40^{\circ} \mathrm{C}(\mathrm{d} \rightarrow \mathrm{a})$, the potentials shifted to more positive direction, the intensity of the peaks increased gradually for both bare $\mathrm{Cd} \mathrm{A}$ ) and S over $\mathrm{Cd}$ B) behaviors, particularly at $40^{\circ} \mathrm{C}$ the current rised from $6.6 \times 10^{-5} \mathrm{~A}$ to $7.4 \times 10^{-5} \mathrm{~A}$ obviously. In the case of $\mathrm{Cd}$ and $\mathrm{S}$ co-deposition $\mathrm{C}$ ), the peak current at $30^{\circ} \mathrm{C}$ reached its maximum value randomly and a general roll-off rate was observed. Therefore, the layer formation of CdS was carried out using ECALE technique as in UPD results of $\mathrm{S}$ over $\mathrm{Cd}$ modified Au electrode, and the increase of the bath temperature improved the crystallinity of the CdS deposit [19].
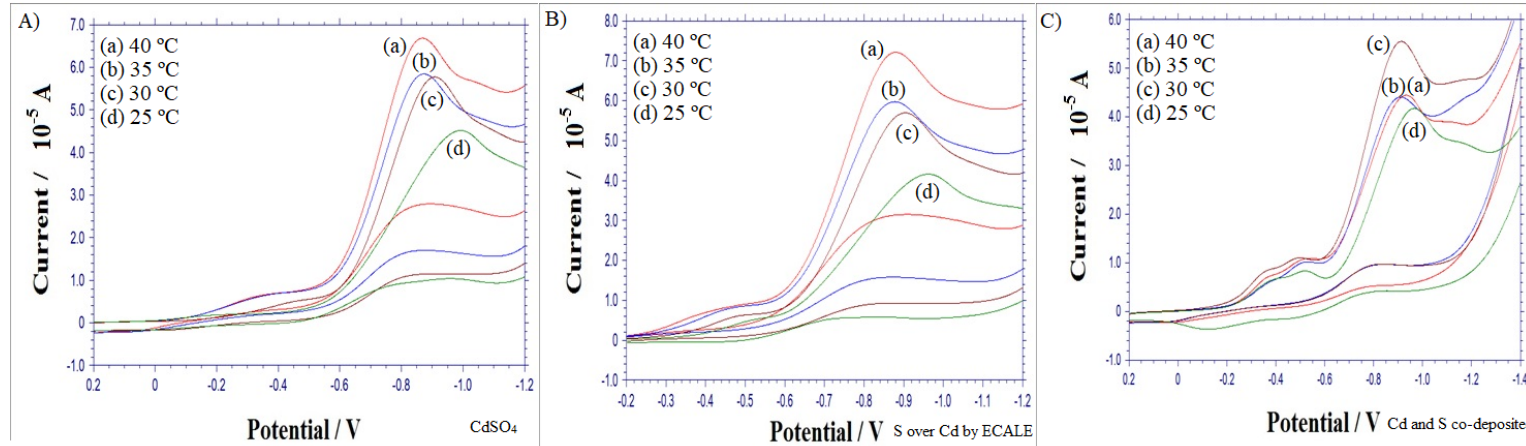

Figure 4. Cyclic voltammograms of coated Au for 10 cycles A) in 0.01 molL $^{-1}$ EDTA containing $\left.0.01 \mathrm{molL}^{-1} \mathrm{CdSO}_{4^{\prime}} \mathrm{B}\right)$ using S over $\mathrm{Cd}$ by ECALE, C) using $\mathrm{Cd}$ and $\mathrm{S}$ by co-deposition techniques in $0.01 \mathrm{molL}^{-1}$ EDTA containing $0.01 \mathrm{molL}^{-1} \mathrm{CdSO}_{4}$ and $0.01 \mathrm{molL}^{-1} \mathrm{Na}_{2} \mathrm{~S}$ between +0.25 and $-1.60 \mathrm{~V}$ versus $\mathrm{Ag} / \mathrm{AgCl}$ at a scan rate of $100 \mathrm{mV} \mathrm{s}^{-1}$, and at a bath temperature of (a) $4^{\circ} \mathrm{C}$, (b) $35^{\circ} \mathrm{C}$, (c) $30^{\circ} \mathrm{C},(\mathrm{d}) 25^{\circ} \mathrm{C}$ 

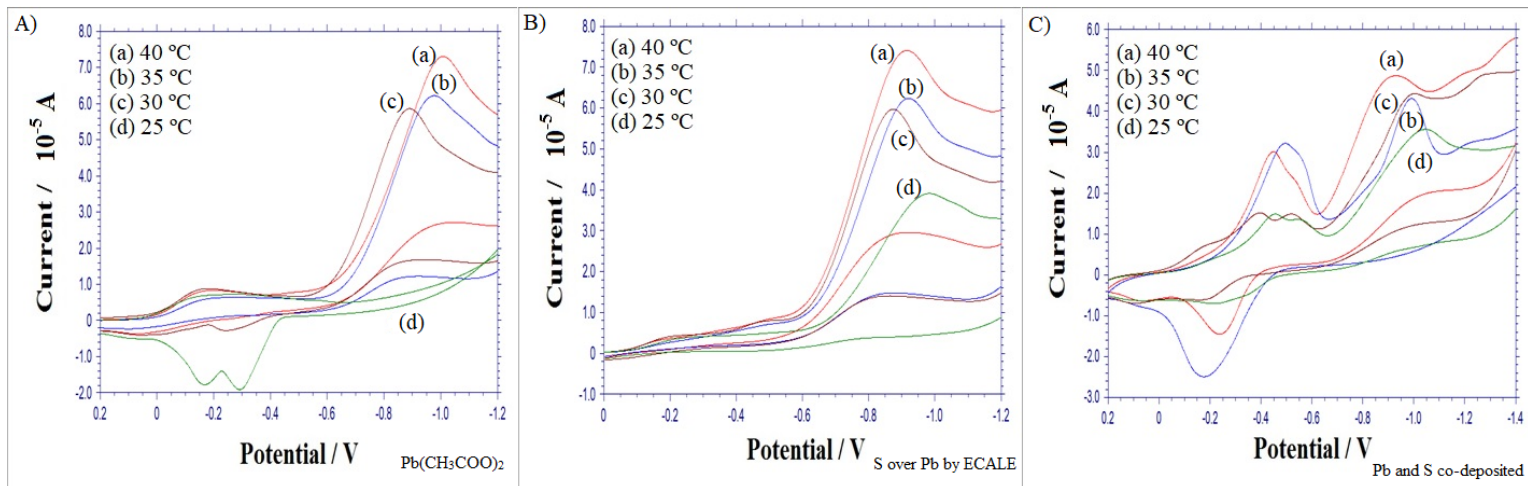

Figure 5. Cyclic voltammograms of coated Au for 10 cycles $\mathrm{A}$ ) in $0.01 \mathrm{molL}^{-1} \mathrm{EDTA}$ containing $\left.0.01 \mathrm{molL}^{-1} \mathrm{~Pb}\left(\mathrm{CH}_{3} \mathrm{COO}\right)_{2}, \mathrm{~B}\right)$ using $\mathrm{S}$ over $\mathrm{Pb}$ by ECALE, C) using Pb and $\mathrm{S}$ by co-deposition techniques in $0.01 \mathrm{molL}^{-1}$ EDTA containing $0.01 \mathrm{molL}^{-1} \mathrm{~Pb}\left(\mathrm{CH}_{3} \mathrm{COO}\right)_{2}$ and $0.01 \mathrm{molL}^{-1} \mathrm{Na}_{2} \mathrm{~S}$ between +0.25 and $-1.60 \mathrm{~V}$ versus $\mathrm{Ag} / \mathrm{AgCl}$ at a scan rate of $100 \mathrm{mV} \mathrm{s}^{-1}$, and at a bath temperature of (a) $40^{\circ} \mathrm{C}$, (b) $35^{\circ} \mathrm{C}$, (c) $30^{\circ} \mathrm{C}$, (d) $25^{\circ} \mathrm{C}$.

(Figure 5) demonstrated the current intensity changes of bare Au electrode in $0.01 \mathrm{molL}^{-1}$ EDTA containing 0.01 molL $\left.\mathrm{L}^{-1} \mathrm{~Pb}\left(\mathrm{CH}_{3} \mathrm{COO}\right)_{2} \mathrm{~A}\right)$, S over $\mathrm{Pb}$ modified Au electrode $\mathrm{B})$, and $\mathrm{Pb}$ and $\mathrm{S}$ co-deposited $\mathrm{Au}$ electrode $\mathrm{C}$ ) in 0.01 molL ${ }^{-1}$ EDTA containing $0.01 \mathrm{molL}^{-1} \mathrm{~Pb}\left(\mathrm{CH}_{3} \mathrm{COO}\right)_{2}$ and 0.01 $\mathrm{molL}^{-1} \mathrm{Na}_{2} \mathrm{~S}$. As the bath temperature increased from $25^{\circ} \mathrm{C}$ to $40^{\circ} \mathrm{C}(\mathrm{d} \rightarrow \mathrm{a})$, the intensity of the peaks increased gradually for both bare $\mathrm{Pb} \mathrm{A}$ ) and $\mathrm{S}$ over $\mathrm{Pb} \mathrm{B}$ ) behaviors. When $\mathrm{Pb}$ UPD peak at $-0.10 \mathrm{~V}$ versus $\mathrm{Ag} / \mathrm{AgCl}$ was taken into account, no peak was observed for $\mathrm{S}$ over $\mathrm{Pb}$ modified Au electrode B). At the lower bath temperatures (c, d), the content of elemental Pb was slightly greater than that of $\mathrm{S} A)$ reaching its current maximum $(-1.80$ $\left.\times 10^{-5} \mathrm{~A}\right)$ and at the higher bath temperatures $(\mathrm{a}, \mathrm{b})$ the content of elemental $\mathrm{Pb}\left(-2.60 \times 10^{-5} \mathrm{~A}\right)$ was slightly less than that of $\left.S\left(+3.40 \times 10^{-5} \mathrm{~A}\right) \mathrm{C}\right)$. Therefore, the layer formation of $\mathrm{PbS}$ was carried out using co-deposition technique as in UPD results of $\mathrm{Pb}$ and $\mathrm{S}$ co-deposited $\mathrm{Au}$ electrode, and the bath temperature had an influence on the composition of the deposited films.

\section{Kinetics of the electrodepositions}

Electrodeposition takes place by a process of nucleation which appears at active sites on the substrate due to nucleation rate law, and growth which occurs by growing via the incorporation of further ions from the solution. Nucleation and growth can be divided into sub-categories such as interfacial controlled and diffusion controlled. In the former, the nucleus growth rate is limited by the speediness at which ions can be incorporated into the new phase. In the later, nucleus growth is limited by the rate at which material is transported through the solution to the electrode surface [20].

The number of various models has been proposed to decide the dominance of adsorption-desorption or nucleation and growth on the chronoamperometric response of systems. Among these models, the evaluation of the current density as the sum of two independent terms, a Langmuir type adsorption-desorption term and a nucleation growth term $\left(j_{\text {total }}=j_{\text {ads }}+j_{\text {nucl }}\right.$ growth $\left._{\text {g }}\right)$ is the simplest one. Such an approach can be applied on the basis where adsorption is typically a rapid process, while nucleation and growth develop more slowly due to kinetic limitations. In the Butler-Volmer model, adsorption-desorption is followed by surface diffusion control of monolayer nucleation and growth [21]. In cases where the two processes are not decoupled, a more complex model such as that of Bosco and Rangarajan is required [22].

In (Figure 6), chronoamperometric results of bare $A u$ A), and coated Au for 10 cycles B) in $0.01 \mathrm{molL}^{-1}$ EDTA containing $0.01 \mathrm{molL}^{-1} \mathrm{CdSO}_{4}$, coated Au for 10 cycles using $\mathrm{Cd}$ and $\mathrm{S}$ by co-deposition $\mathrm{C}$ ), and coated Au for 10 cycles using $\mathrm{Cd}$ over $\mathrm{S}$ by ECALE D) techniques in 0.01 molL ${ }^{-1}$ EDTA containing $0.01 \mathrm{molL}^{-1} \mathrm{CdSO}_{4}$ and $0.01 \mathrm{molL}^{-}$ ${ }^{1} \mathrm{Na}_{2} \mathrm{~S}$ were estimated. In all conditions, the current density $(j)$ decreased as a function of elapsing time ( $t$ $<0.03 \mathrm{~s}$ ), right from the start of the transient resulted in no nucleation model giving a clear description of the transient shape. For $\mathrm{t}>0.03 \mathrm{~s}$, the shape of transient supported the formation and growth of $2 \mathrm{D}$ nuclei, limited by ad-atom incorporation. As it could be seen in (Figure 6) from B) to D), a current enhancement appeared in $\mathrm{Cd}$ monolayer formation and it proceeded by a two-step mechanism involving Langmuir-type adsorption accompanied by nucleation and two dimensional growth. Therefore, $\mathrm{Cd}$ deposition was described by the 

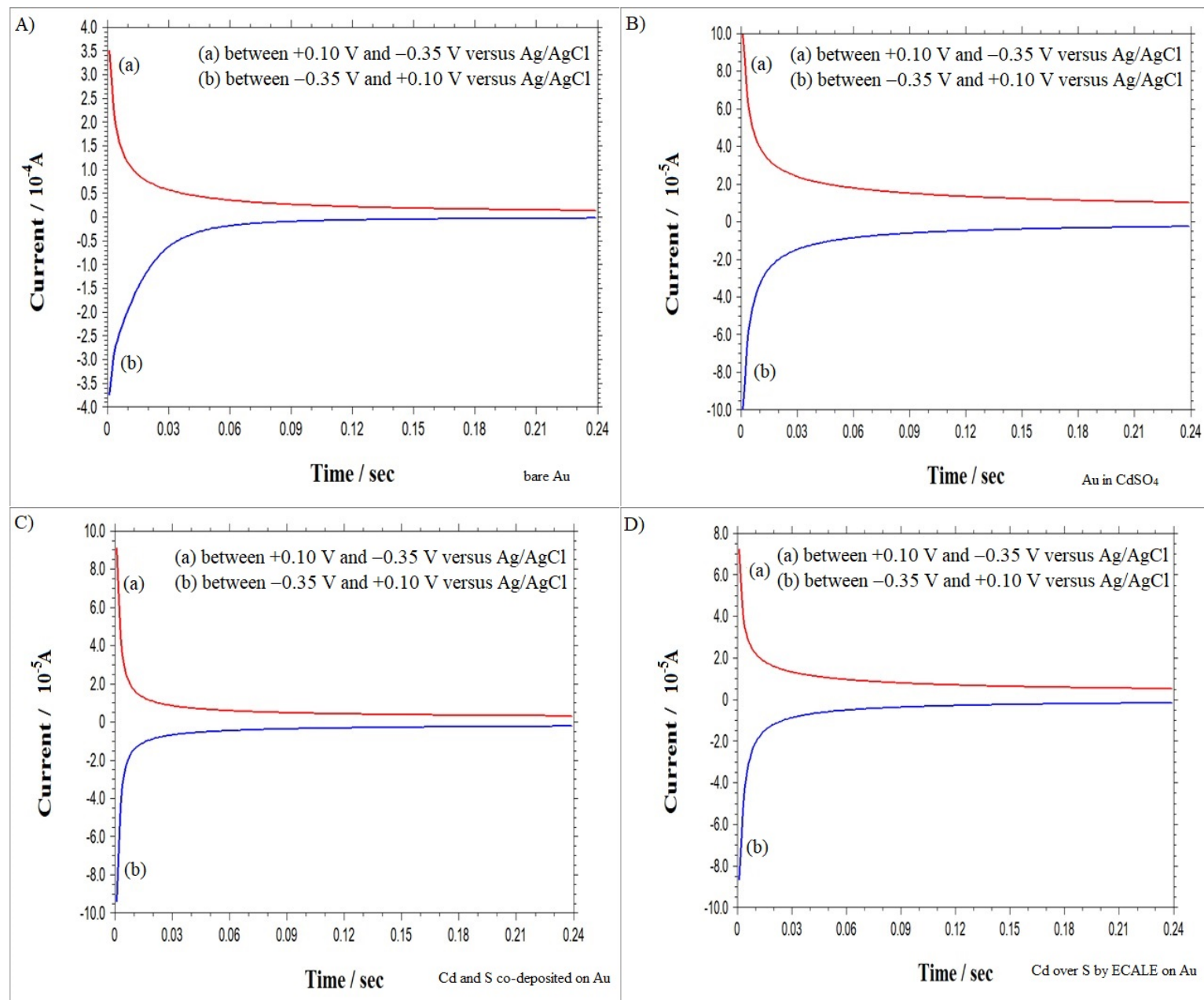

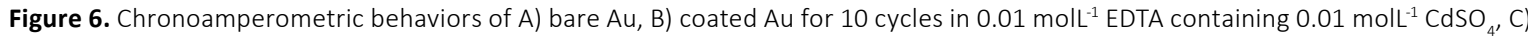
coated Au for 10 cycles using $\mathrm{Cd}$ and $\mathrm{S}$ by co-deposition, D) coated Au for 10 cycles using Cd over S by ECALE techniques in $0.01 \mathrm{molL}^{-1}$ EDTA containing 0.01 molL $^{-1} \mathrm{CdSO}_{4}$ and $0.01 \mathrm{molL}^{-1} \mathrm{Na}_{2} \mathrm{~S}$ between (a) $+0.10 \mathrm{~V}$ and $-0.35 \mathrm{~V}$ versus Ag/AgCl and (b) $-0.35 \mathrm{~V}$ and $+0.10 \mathrm{~V}$ versus $\mathrm{Ag} / \mathrm{AgCl}$.

model $\left(j_{\text {total }}=j_{A D}+j_{2 D}\right)$ used by Hölzle et al. [23] in which the electrodeposition process $\left(j_{\text {total }}\right)$ was the linear sum of a Langmuir-type adsorption term $\left(j_{A D}\right)$ and a $2 \mathrm{D}$ nucleation process $\left(j_{20}\right)$.

In order to analyze the experimental data by usual procedures, the plots of / versus $t^{1 / 2}$ for bare Au A) and coated Au for 10 cycles B) in 0.01 molt $^{-1}$ EDTA containing 0.01 moll $^{-1} \mathrm{CdSO}_{4^{\prime}}$, coated Au for 10 cycles using $\mathrm{Cd}$ and $\mathrm{S}$ by co-deposition C), and coated Au for 10 cycles using Cd over $S$ by ECALE D) techniques in $0.01 \mathrm{molL}^{-1}$ EDTA containing $0.01 \mathrm{molL}^{-1} \mathrm{CdSO}_{4}$ and $0.01 \mathrm{molL}^{-1} \mathrm{Na}_{2} \mathrm{~S}$ recorded between (a) $+0.10 \mathrm{~V}$ and $-0.35 \mathrm{~V}$ versus $\mathrm{Ag} / \mathrm{AgCl}$ and (b) $-0.35 \mathrm{~V}$ and $+0.10 \mathrm{~V}$ versus $\mathrm{Ag} / \mathrm{AgCl}$ were given in (Figure 7).
The resulting straight line in all curves (Table 1 ) showed a diffusion-controlled process according to the Cottrell equation [24] and the higher the slope of graph was obtained in (Figure $7 \mathrm{~A}$ ) because of the metal ion behavior of $\mathrm{Au}$. For the electrodeposition of $\mathrm{Cd}$ from $\mathrm{B}$ ) to $D)$, the slopes namely diffusion coefficients $(D \sim 1 / \eta)$ reduced normally because of the absolute viscosity $(\eta)$ which was greater for thin films in comparison with free metals.

For the higher potentials, nucleation and growth properties come forward in the chronoamperometry; the reduction current increases until it reaches a maximum with a later decline with time and diffusion becomes the rate-limiting process. Different nucleation and 


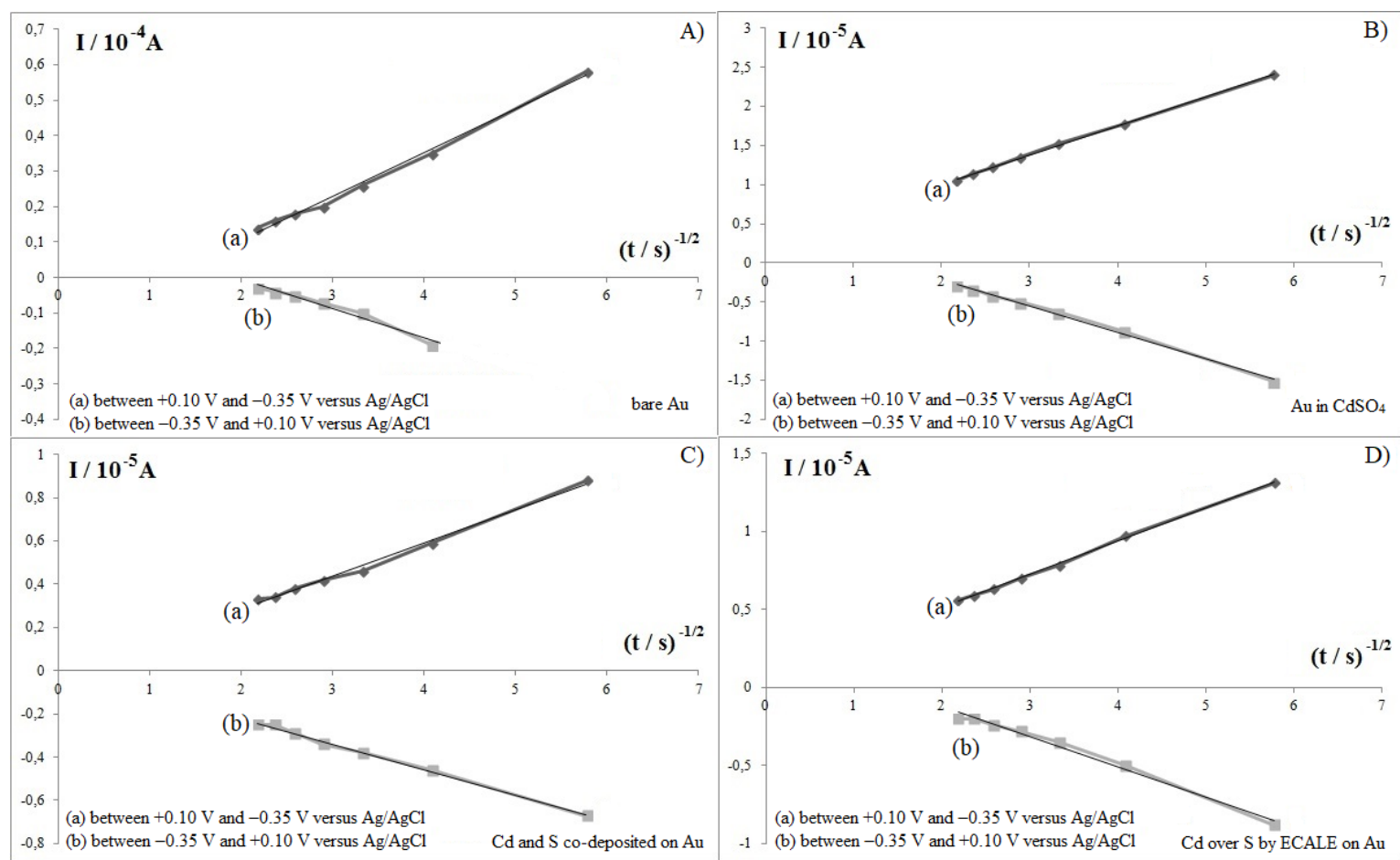

Figure 7. The plots of I versus $\mathrm{t}^{-1 / 2}$ indicating the current transients of bare Au A), coated Au for 10 cycles B), coated Au for 10 cycles using $\mathrm{Cd}$ and $\mathrm{S}$ by co-deposition $\mathrm{C}$ ), and coated Au for 10 cycles using $\mathrm{Cd}$ over $\mathrm{S}$ by ECALE D) recorded between two potential ranges (+0.10 $\mathrm{V}$ $-(-0.35 \mathrm{~V})$ versus $\mathrm{Ag} / \mathrm{AgCl}$ and $-0.35 \mathrm{~V}-(+0.10 \mathrm{~V})$ versus $\mathrm{Ag} / \mathrm{AgCl})$, see in (Figure 6$)$. Two lines surrounding markers showed the linearity $\left(R^{2}\right.$ in Table 1$)$ and straight line passing through the points.

growth mechanisms were considered in the analysis of the potential step data, and the experimental data was found to be best described using the 3D instantaneous, diffusion-controlled nucleation and growth mechanism [25].

(Figure 8) represented chronoamperometric responses of bare Au A) and coated Au for 10 cycles B) in 0.01 molL ${ }^{1}$ EDTA containing $0.01 \mathrm{molL}^{-1} \mathrm{~Pb}\left(\mathrm{CH}_{3} \mathrm{COO}\right)_{2}$, coated $\mathrm{Au}$ for 10 cycles using $\mathrm{Pb}$ and $\mathrm{S}$ by co-deposition $\mathrm{C}$ ), and coated Au for 10 cycles using Pb over S by ECALE D) techniques in $0.01 \mathrm{molL}^{-1}$ EDTA containing $0.01 \mathrm{molL}$ ${ }^{1} \mathrm{~Pb}\left(\mathrm{CH}_{3} \mathrm{COO}\right)_{2}$ and $0.01 \mathrm{molL}^{-1} \mathrm{Na}_{2} \mathrm{~S}$. A current decline from $\mathrm{A}$ ) to $\mathrm{C}$ ) was observed by $\mathrm{Pb}$ monolayer formation, but when $\mathrm{Pb}$ monolayer was formed over $\mathrm{S}$ modified $\mathrm{Au}$ electrode $D$ ), the current increased again. It proceeded by a two-step mechanism involving 3D instantaneous, diffusion-controlled nucleation and growth mechanism.

In (Figure 9), the plots of $I$ versus $t^{1 / 2}$ and $t^{1 / 2}$ for bare $\mathrm{Au} A$ ) and coated Au for 10 cycles B) in $0.01 \mathrm{molL}^{-1}$ EDTA containing $0.01 \mathrm{molL}^{-1} \mathrm{~Pb}\left(\mathrm{CH}_{3} \mathrm{COO}\right)_{2}$, coated Au for 10 cycles using $\mathrm{Pb}$ and $\mathrm{S}$ by co-deposition $\mathrm{C}$ ), and coated Au for 10 cycles using Pb over $\mathrm{S}$ by ECALE D) techniques in $0.01 \mathrm{molL}^{-1}$ EDTA containing $0.01 \mathrm{molL}^{-1} \mathrm{~Pb}\left(\mathrm{CH}_{3} \mathrm{COO}\right)_{2}$ and $0.01 \mathrm{molL}^{-1} \mathrm{Na}_{2} \mathrm{~S}$ recorded between $+0.60 \mathrm{~V}$ and (a) $-0.43 \mathrm{~V}$ versus $\mathrm{Ag} / \mathrm{AgCl}$, (b) $-0.44 \mathrm{~V}$ versus $\mathrm{Ag} / \mathrm{AgCl}$, (c) $-0.45 \vee$ versus $\mathrm{Ag} / \mathrm{AgCl}$, (d) $-0.46 \vee$ versus $\mathrm{Ag} / \mathrm{AgCl}$ were indicated.

Table 1. Equations and coefficients of determination for the plots of I versus $t^{-1 / 2}$

\begin{tabular}{|c|c|c|c|c|}
\hline Potential Range (V) & Bare Au & $\mathrm{Au}$ in $\mathrm{CdSO}_{4}$ & $\begin{array}{c}\text { Cd and S co-deposited } \\
\text { on Au }\end{array}$ & $\begin{array}{c}\text { Cd over S by ECALE } \\
\text { on } \mathrm{Au}\end{array}$ \\
\hline$+0.10-(-0.35)$ & $\begin{array}{c}y=0.1228 x-0.1396 \\
R^{2}=0.9943\end{array}$ & $\begin{array}{c}y=0.3714 x+0.2626 \\
R^{2}=0.9991\end{array}$ & $\begin{array}{c}y=0.1541 x-0.0247 \\
R^{2}=0.9928\end{array}$ & $\begin{array}{c}y=0.2121 x+0.0888 \\
R^{2}=0.9986\end{array}$ \\
\hline$-0.35-(+0.10)$ & $\begin{array}{c}y=-0.0826 x+0.1599 \\
R^{2}=0.9656\end{array}$ & $\begin{array}{c}y=-0.3408 x+0.4747 \\
R^{2}=0.9965\end{array}$ & $\begin{array}{c}y=-0.1183+0.0148 \\
R^{2}=0.9963\end{array}$ & $\begin{array}{c}y=-0.1930 x+0.2610 \\
R^{2}=0.9878\end{array}$ \\
\hline
\end{tabular}




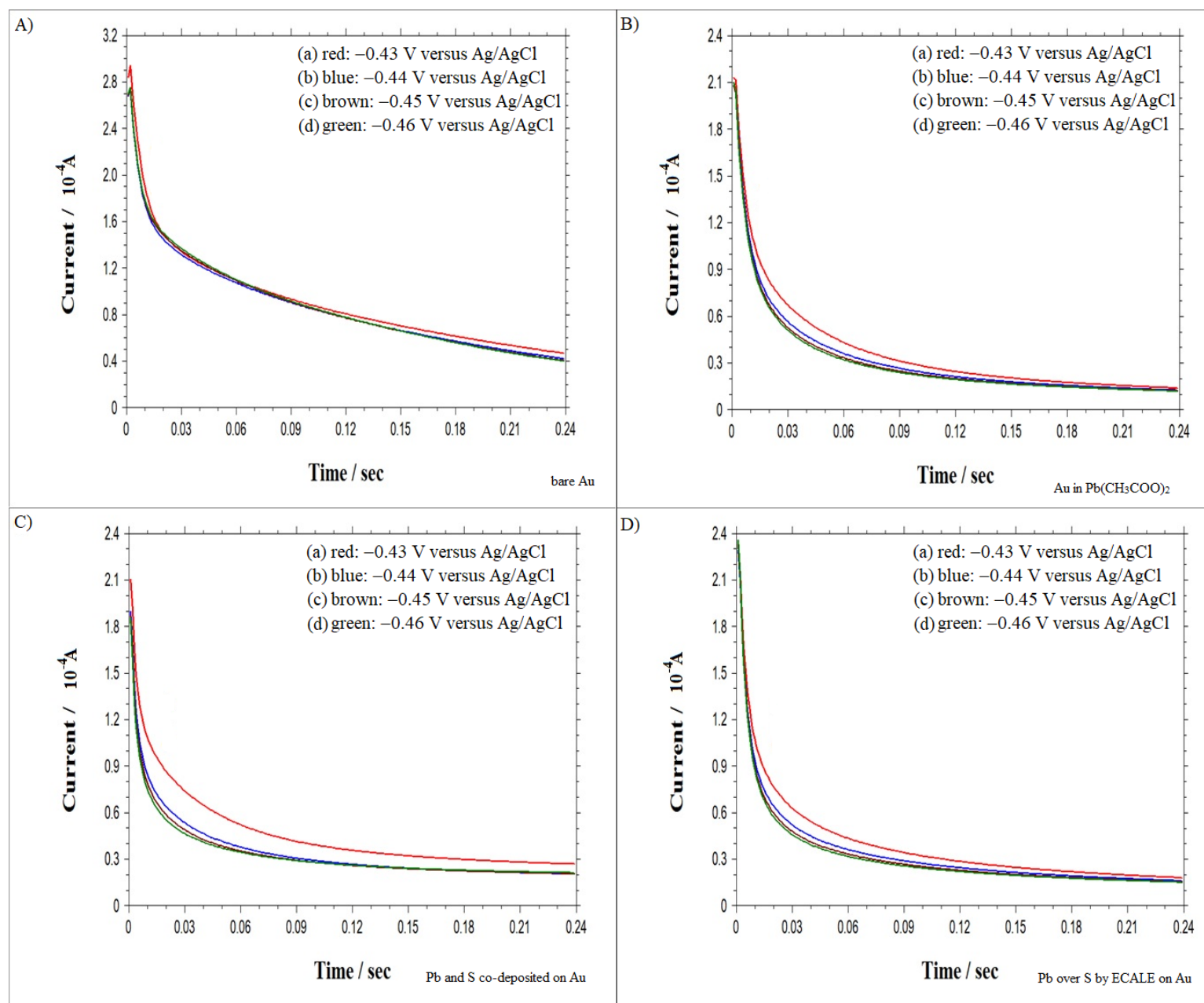

Figure 8. Chronoamperometric behaviors of A) bare $\mathrm{Au}, \mathrm{B})$ coated Au for 10 cycles in $0.01 \mathrm{molL}^{-1}$ EDTA containing $0.01 \mathrm{molL}^{-1} \mathrm{~Pb}\left(\mathrm{CH}_{3} \mathrm{COO}\right)_{2}$, C) coated Au for 10 cycles using Pb and S by co-deposition, D) coated Au for 10 cycles using Pb over $\mathrm{S}$ by ECALE techniques in $0.01 \mathrm{molL}^{-1}$ EDTA containing $0.01 \mathrm{molL}^{-1} \mathrm{~Pb}\left(\mathrm{CH}_{3} \mathrm{COO}\right)_{2}$ and $0.01 \mathrm{molL}^{-1} \mathrm{Na}_{2} \mathrm{~S}$ between $+0.60 \mathrm{~V}$ and (a) $-0.43 \mathrm{~V}$ versus Ag/AgCl, (b) $-0.44 \mathrm{~V}$ versus Ag/ $\mathrm{AgCl}$, (c) $-0.45 \mathrm{~V}$ versus $\mathrm{Ag} / \mathrm{AgCl}$, (d) $-0.46 \mathrm{~V}$ versus $\mathrm{Ag} / \mathrm{AgCl}$

For only (Figure $9 \mathrm{~A}$ ), the graph of $/$ versus $t^{1 / 2}$ was drawn because of the bent curve of $I$ versus $t^{1 / 2}$, and the resulting linearity was obtained by the bare $\mathrm{Au}$ (Table 2). For the electrodeposition of $\mathrm{Pb}$ from $\mathrm{B}$ ) to $\mathrm{D}$ ), the diffusion coefficients $(D \sim 1 / \eta)$ based on the slopes declined normally because of the absolute viscosity $(\eta)$ which was greater for deposits in comparison with free metals B).

\section{Conclusion}

A simple and new route for the electrodeposition of $\mathrm{CdS}$ and $\mathrm{PbS}$ based on co-deposition and ECALE techniques was improved as a one-step and cost-effective process. Two different methods to produce semiconducting materials were examined in detail onto polycrystalline electrodes for the first time. Various electrochemical deposition processes such as bulk electrolysis and cyclic voltammetry were used to determine the best layer formation. The effect of bath temperature on UPD was studied to estimate the quality and crystallinity of deposits, and the temperature results were in a good correlation with UPD responses of $\mathrm{CdS}$ and $\mathrm{PbS}$. To decide the kinetic behaviors of deposits, another electrochemical technique namely which was chronoamperometry was performed, and two-step mechanism involving adsorption accompanied by nucleation and growth was obtained. In summary, UPD was applied on both pure metals and deposits by means of this work, 

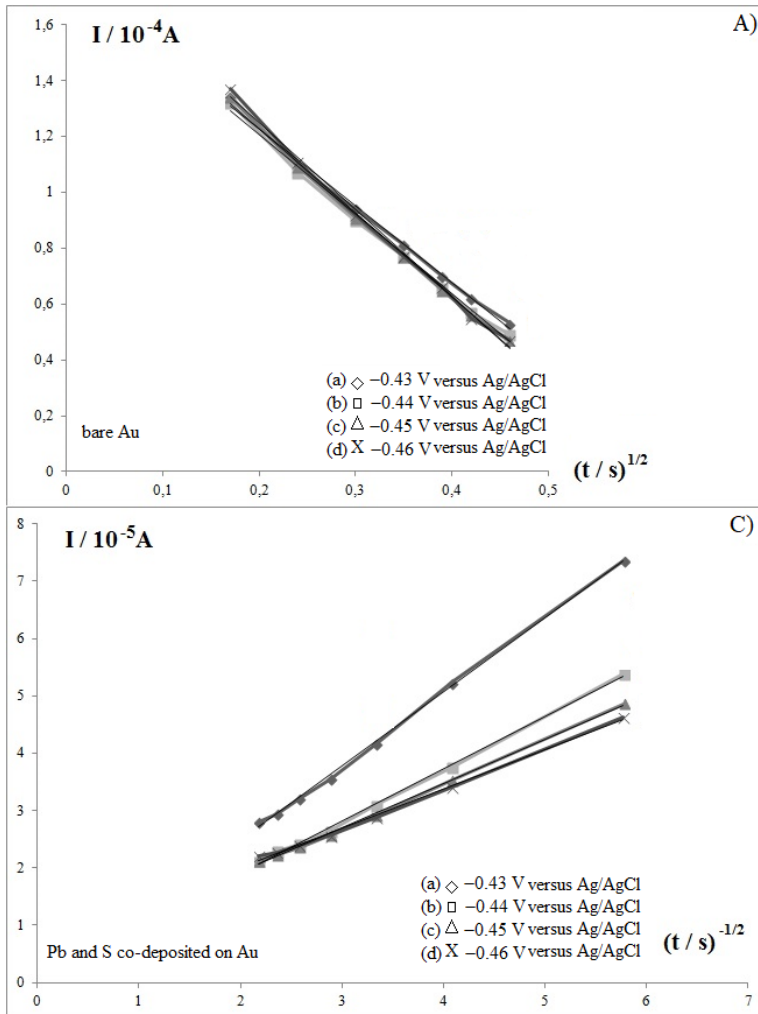

A) 8

$\mathbf{I} / 10^{-5} \mathrm{~A}$

B)

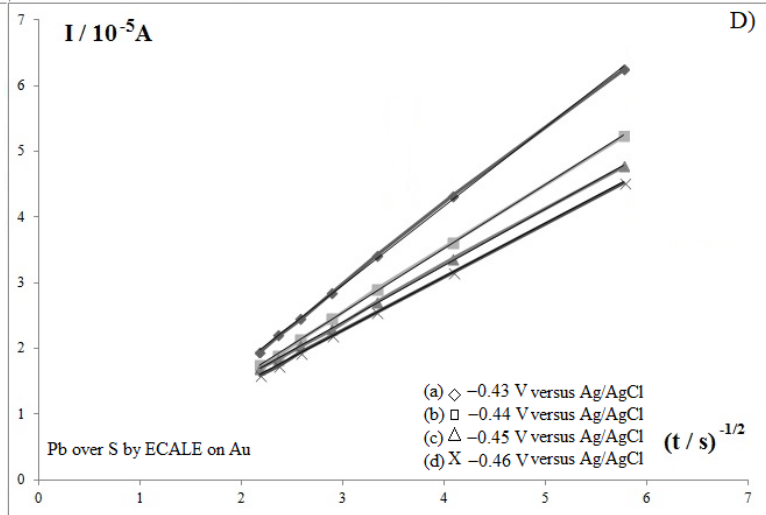

Figure 9. The plots of I versus $t^{1} / 2$ and $t-1 / 2$ indicating the current transients of bare $A u A$ ), coated Au for 10 cycles $B$ ), coated Au for 10 cycles using $\mathrm{Pb}$ and $\mathrm{S}$ by co-deposition $\mathrm{C}$ ), and coated Au for 10 cycles using Pb over $\mathrm{S}$ by ECALE D) recorded between four potential ranges $(+0.60 \mathrm{~V}-(-0.43 \mathrm{~V}),(-0.44 \mathrm{~V}),(-0.45 \mathrm{~V}),(-0.46 \mathrm{~V})$ versus $\mathrm{Ag} / \mathrm{AgCl})$, see in (Figure 8$)$. Two lines surrounding markers showed the linearity $\left(R^{2}\right.$ in Table 2$)$ and straight line passing through the points.

Table 2. Equations and coefficients of determination for the plots of I versus $t^{1 / 2}$ and I versus $t^{-1 / 2}$

\begin{tabular}{|c|c|c|c|c|}
\hline Potential Range (V) & Bare Au & $\mathrm{Au}$ in $\mathrm{Pb}\left(\mathrm{CH}_{3} \mathrm{COO}\right)_{2}$ & $\begin{array}{c}\mathrm{Pb} \text { and } \mathrm{S} \text { co-deposited } \\
\text { on } \mathrm{Au}\end{array}$ & $\begin{array}{c}\mathrm{Pb} \text { over } \mathrm{S} \text { by ECALE } \\
\text { on } \mathrm{Au}\end{array}$ \\
\hline$+0.60-(-0.43)$ & $\begin{array}{c}y=-2.7545 x+1.7783 \\
R^{2}=0.9955\end{array}$ & $\begin{array}{c}y=1.4679 x-1.7302 \\
R^{2}=0.9992\end{array}$ & $\begin{array}{c}y=1.2905 x-0.0938 \\
R^{2}=0.9989\end{array}$ & $\begin{array}{c}y=1.1969 x-0.6208 \\
R^{2}=0.9993\end{array}$ \\
\hline$+0.60-(-0.44)$ & $\begin{array}{c}y=-2.8487 x+1.7739 \\
R^{2}=0.9651\end{array}$ & $\begin{array}{c}y=1.2163 x-1.345 \\
R^{2}=0.9993\end{array}$ & $\begin{array}{c}y=0.9104 x+0.0869 \\
R^{2}=0.9983\end{array}$ & $\begin{array}{c}y=0.9748 x-0.3780 \\
R^{2}=0.9997\end{array}$ \\
\hline$+0.60-(-0.45)$ & $\begin{array}{c}y=-3.1131 x+1.8719 \\
R^{2}=0.9959\end{array}$ & $\begin{array}{c}y=1.1062 x-1.1462 \\
R^{2}=0.9982\end{array}$ & $\begin{array}{c}y=0.7709 x+0.3862 \\
R^{2}=0.9987\end{array}$ & $\begin{array}{c}y=0.8615 x-0.1841 \\
R^{2}=0.9998\end{array}$ \\
\hline$+0.60-(-0.46)$ & $\begin{array}{c}y=-2.9971 x+1.8247 \\
R^{2}=0.9969\end{array}$ & $\begin{array}{c}y=1.0583 x-1.0759 \\
R^{2}=0.9987\end{array}$ & $\begin{array}{c}Y=0.6849 x+0.6410 \\
R^{2}=0.9973\end{array}$ & $\begin{array}{c}y=0.8143 x-0.1690 \\
R^{2}=0.9999\end{array}$ \\
\hline
\end{tabular}


so the proposed method may serve as a model for semiconducting industry and environmental science.

\section{References}

1. T. Noyhouzer, D. Mandler, Determination of low levels of cadmium ions by the under potential deposition on a selfassembled monolayer on gold electrode, Anal. Chim. Acta, 684 (2011) 1-7.

2. T. Peng, H. Yang, K. Dai, X. Pu, K. Hirao, Fabrication and characterization of $\mathrm{CdS}$ nanotube arrays in porous anodic aluminum oxide templates, Chem. Phys. Lett., 379 (2003) 432-436.

3. M. Alanyalıoğlu, F. Bayrakçeken, Ü. Demir, Preparation of PbS thin films: A new electrochemical route for underpotential deposition, Electrochim. Acta, 54 (2009) 6554-6559.

4. M.M. Momeni, A.A. Mozafari, The effect of number of SILAR cycles on morphological, optical and photo catalytic properties of cadmium sulfide-titania films, J. Mater. Sci. Mater. El., 27 (2016) 10658-10666.

5. M.M. Momeni, M. Mahvari, Y. Ghaveb, Photoelectrochemical properties of iron-cobalt WTiO2 nanotube photoanodes for water splitting and photocathodic protection of stainless steel, J. Electroanal. Chem., 832 (2019) 7-23.

6. S. Taguchi, M. Kondo, H. Mori, A. Aramata, Formation of zinc-oxianion complex adlayer by underpotential deposition of $\mathrm{Zn}$ on $\mathrm{Au}(111)$ electrode: Preferential formation of zinc monohydrogen phosphate complex in weakly acidic solutions, Electrochim. Acta, 111 (2013) 642-655.

7. J.O'M. Bockris, A.K.N. Reddy, M. Gamboa-Aldeco, Modern Electrochemistry, 2nd Ed., Vol. 2A, Kluwer Academic/ Plenum Publishers, 2000

8. i..Y. Erdoğan, T. Öznülüer, F. Bülbül, Ü. Demir, Characterization of size-quantized PbTe thin films synthesized by an electrochemical co-deposition method, Thin Solid Films, 517 (2009) 5419-5424

9. I. Sisman, M. Alanyalioglu, U. Demir, Atom-by-Atom Growth of CdS Thin Films by an Electrochemical Co-deposition Method: Effects of $\mathrm{pH}$ on the Growth Mechanism and Structure, J. Phys. Chem. C, 111 (2007) 2670-2674.

10. T. Oznuluer, I. Erdogan, I. Sisman, U. Demir, Electrochemical atom-by-atom growth of PbS by modified ECALE method, Chem. Mater. 17 (2005) 935-937.
11. X. Zhang, X. Shi, C. Wang, Optimization of electrochemica aspects for epitaxial depositing nanoscale ZnSe thin films, J. Solid State Electrochem., 13 (2009) 469-475.

12. J.L. Stickney, The Chalkboard: Electrochemical Atomic Layer Deposition, Electrochem. Soc. Interf., 20 (2011) 28-30.

13. V. Sudha, M.V. Sangaranarayanan, Underpotential deposition of metals - Progress and prospects in modelling, J. Chem. Sci., 117 (2005) 207-218.

14. i. Şişman, Ü. Demir, Electrochemical growth and characterization of size-quantized CdTe thin films grown by underpotential deposition, J. Electroanal. Chem, 651 (2011) 222-227.

15. J. Puiso, S. Tamulevicius, G. Laukaitis, S. Lindroos, M. Leskela, V. Snitka, Growth of PbS thin films on silicon substrate by SILAR technique, Thin Solid Films, 403 (2002) 457-461.

16. M. Biçer, A.O. Aydın, I. Şşsman, Electrochemical synthesis of $\mathrm{CdS}$ nanowires by underpotential deposition in anodic alumina membrane templates, Electrochim. Acta, 55 (2010) 3749-3755.

17. D. Fernando, M. Khan, Y. Vasquez, Control of the crystalline phase and morphology of CdS deposited on microstructured surfaces by chemical bath deposition, Mater. Sci. Semicond. Process., 30 (2015) 174-180.

18. W. Zhu, J.Y. Yang, X.H. Gao, J. Hou, S.Q. Bao, X.A. Fan, The underpotential deposition of bismuth and tellurium on cold rolled silver substrate by ECALE, Electrochim. Acta, 50 (2005) 5465-5472.

19. S. Cheng, G. Chen, Y. Chen, C. Huang, Effect of deposition potential and bath temperature on the electrodeposition of SnS film, Opt. Mater., 29 (2006) 439-444.

20. M.E. Hyde, R.G. Compton, A review of the analysis of multiple nucleation with diffusion controlled growth, J. Electroanal. Chem., 549 (2003) 1-12.

21. H.V.M. Hamelers, A. ter Heijne, N. Stein, R.A. Rozendal, C.J.N. Buisman, Butler-Volmer-Monod model for describing bioanode polarization curves, Bioresour. Technol., 102 (2011) 381-387.

22. U. Demir, C. Shannon, Electrochemistry of $\mathrm{Cd}$ at $(\mathrm{V} 3 \times \sqrt{ } 3)$ $\mathrm{R} 30^{\circ}-\mathrm{S} / \mathrm{Au}(111)$ : Kinetics of Structural Changes in $\mathrm{CdS}$ Monolayers, Langmuir, 12 (1996) 6091-6097.

23. M.H. Hölzle, C.W. Apsel, T. Will, D.M. Kolb, Copper Deposition onto $\mathrm{Au}(111)$ in the Presence of Thiourea, J. Electrochem. Soc., 142 (1995) 3741-3749.

24. F.G. Cottrell, Der reststrom bei galvanischer polarisation, betrachtet als ein diffusionsproblem, Z. Physik Chem., 42 (1902) 385-431.

25. I. Petersson, E. Ahlberg, Kinetics of the electrodeposition of Pb@Sn alloys: Part I. At glassy carbon electrodes, J. Electroanal. Chem., 485 (2000) 166-177. 